\title{
ANALISIS PERLAKUAN AKUNTANSI ASET TETAP PADA BADAN KEPEGAWAIAN DAN DIKLAT (BKD) KOTA MANADO
}

\author{
Oleh: \\ Yefta Masipuang ${ }^{1}$ \\ Ventje Ilat ${ }^{2}$ \\ Sherly Pinatik
}

\author{
Fakultas Ekonomi dan Bisnis \\ UniversitasSamRatulangi Manado \\ Email: 1prince_jephtha@yahoo.com
}

\begin{abstract}
This study aimed to analyze the accounting treatment for fixed assets in Manado what BKD in accordance with Regulation 71 Year 2010 Statement of Government Accounting Standards (PSAP) No. 07 on fixed assets. The method used is descriptive analysis method with a way of understanding reality and compare it with the theory that the researchers studied so it can be concluded. In the research entity accounting treatment of fixed assets has been good. In practice, in the way of acquisition of fixed assets of the entity making a purchase in cash, the entity has not shrunk its fixed assets where it is not in accordance with the Governmental Accounting Standards applicable, the entities stop fixed assets that are not used by way of eliminating it from the balance sheet and transferred to the post of other fixed assets, as well as in the presentation and disclosure, the entity has revealed the fixed assets in accordance with accounting standards applicable rule.
\end{abstract}

Keywords: Fixed Assets, PSAP NO. 07

\section{PENDAHULUAN}

Salah satu kebijakan pemerintah Republik Indonesia yang memiliki pengaruh starategis yang dideklarasikan pada tahun 1999 adalah Otonomi Daerah. Otonomi. Otonomi daerah adalah hak, wewenang, dan kewajiban daerah otonom untuk mengatur dan mengurus sendiri urusan pemerintahan dan kepentingan masyarakat setempat sesuai dengan peraturan perundang-undangan (UU RI Nomor 32 Tahun 2014 Pasal 1 ayat 5).Keberadaan kebijakan pemerintah tentang Otonomi daerah secara langsung mengharuskan setiap provinsi, kabupaten, dan kota yang ada di Indonesia untuk melakukan pengelolaan dan pertanggungjawaban keuangannya sendiri.

Aset adalah sumber daya ekonomi yang dikuasai dan/atau dimiliki oleh pemerintah sebagai akibat dari peristiwa masa lalu dan dari mana manfaat ekonomi dan/atau sosial di mana masa depan diharapkan dapat diperoleh, baik oleh pemerintah,masyarakat, serta dapat diukur dalam satuan uangAset tetap merupakan salah satu klasifikasi aset yang merupakan aset berwujud yang mempunyai masa manfaat lebih dari 12 (dua belas) bulan untuk digunakan, atau dimaksudkan untuk digunakan, dalam kegiatan pemerintah atau dimanfaatkan oleh masyarakat umum (Standar Akuntansi Pemerintahan Pernyataan No. 07). Didalam melaksanakan kegiatan pemerintahan, pemerintah tidak lepas dari penggunaaan aset tetap untuk itu mengapa aset tetap sering merupakan suatu bagian utama aset pemerintah, dan karenanya signifikan dalam penyajian neraca. Di dalam laporan keuangan, perkiraan suatu aset tetap nilainya material sehingga dapat mempengaruhi besar kecilnya jumlah aset yang tercantum di neraca yang secara otomatis akan mempengaruhi para pemakai laporan keuangan dalam mengambil keputusanStandar Akuntansi Pemerintahan merupakan pedoman yang disusun oleh Komite Standar Akuntansi Pemerintahan (KSAP) yang independen dan ditetapkan dengan peraturan pemerintah setelah terlebih dahulu mendapat pertimbangan dari Badan Pemeriksa Keuangan (BPK) .

Badan Kepegawaian dan Diklat (BKD) merupakan salah satu Satuan Kerja Perangkat Daerah (SKPD) yang ada di wilayah Pemerintahan Kota Manado yang mempunyai tugas pokok untuk membantu Walikota sebagai Pejabat pembina kepegawaian daerah kota Manado dalam melaksanakan 
manajemen kepegawaian daerah berdasarkan Peraturan Walikota Manado Nomor 38 Tahun 2008 sekaligus sebagai pelaksana anggaran. Sebagai pelaksana anggaran, Badan Kepegawaian dan Diklat (BKD) Kota Manado harus membuat pertanggungjawaban atas kewenangan yang dilaksanakannya sesuai dengan Peraturan Pemerintah Nomor 71 Tahun 2010 Tentang Standar Akuntansi Pemerintahan.

Badan Kepegawaian dan Diklat (BKD) Kota Manado memiliki Aset Tetap yang dipergunakan dalam menunjang kegiatan pemerintahan. Total Aset Tetap yang dimiliki oleh BKD Kota Manado adalah sebesar Rp. 1.122.122.150. Dengan nominal aset tetap yang dimiliki tersebut sudah seharusnya BKD Kota Manado melakukan perlakuan atas aset tetap dengan benar. Perlakuan akuntansi atas aset tetap yang dilakukan oleh Badan Kepegawaian dan Diklat (BKD) hampir semuanya telah sesuai dengan standar pemerintahan yang berlaku, namun hingga saat ini BKD Kota Manado belum pernah melakukan penyusutan terhadap aset tetap yang dimiliki padahal penyusutan terhadap aset tetap sangatlah penting..

Berdasarkan latar belakang diatas, peneliti tertarik mengambil judul untuk penelitian ini yaitu : "Analisis Perlakuan Akuntansi Aset Tetap pada Badan Kepegawaian dan Diklat (BKD) Kota Manado"

\section{Tinjauan Pustaka}

Ismail (2010:2), mengatakan akuntansi adalah seni dalam mencatat, menggolongkan dan mengikhtisarkan semua transaksi-transaksi yang terkait dengan keuangan yang telah terjadi dengan suatu cara yang bermakna dan dalam satuan uang. Menurut Sodikin \& Riyono akuntansi dapat diklasifikasi atas dasar : (1) entitas ekonomik yang menggunakan akuntansi dan (2) para pengguna informasi akuntansi.

Akuntansi juga dapat diklasifikasikan berdasar siapa pengguna yang menjadi pusat perhatiannya. Atas dasar focus ini, akuntansi diklasifikasi menjadi akuntansi keuangan dan akuntansi manajemen. Akuntansi keuangan menyajikan informasi terutama untuk kepentingan pihak eksternal entitas ekonomik. Di antara para pihak eksternal tersebut, pengguna yang utama adalah para pemilik perusahaan (pemegang saham) dan para kreditur. Akuntansi Manajemen menyajikan infromasi untuk kepentingan pihak internal entitas ekonomik, yaitu manajemen yang berfungsi mengelola perusahaan.

Ghozali dan Ratmono (2008:3) menyatakan bahwa dalam akuntansi pemerintahan data akuntansi digunakan untuk memberikan infomasi mengenai transaksi ekonomi dan keuangan yang menyangkut organisasi pemerintahan dan organisasi-organisasi lain yang tidak bertujuan mencari laba (non-profit organization).

Aset Tetap merupakan salah satu elemen dari aset pada neraca yang digunakan dalam laporan keuangan suatu SKPD. Pada umumnya setiap Satuan Kerja Perangkat Daerah (SKPD) memiliki aset tetap untuk menunjang kegiatan yang dilakukan. Definisi aset tetap menurut Standar Akuntansi Pemerintahan (PP No.71 tahun 2010 pernyataan No. 07) : Aset Tetap adalah aset berwujud yang mempunyai masa manfaat lebih dari 12 (dua belas) bulan untuk digunakan, atau dimaksudkan untuk digunakan, dalam kegiatan pemerintah atau dimanfaatkan oleh masyarakat umum.

Menurut Standar Akuntansi Pemerintah, suatu aset dapat diakui sebagai aset tetap apabila berwujud dan memenuhi kriteria : (a)Mempunyai masa manfaat lebih dari 12 (dua belas) bulan;(b) Biaya perolehan aset dapat diukur secara andal; (c) Tidak dimaksudkan untuk dijual dalam operasi normal entitas; dan (d) Diperoleh atau dibangun dengan maksud untuk digunakan. Aset tetap dinilai dengan biaya perolehan. Apabila penilaian aset tetap dengan menggunakan biaya perolehan tidak memungkinkan maka nilai aset tetap didasarkan pada nilai wajar pada saat perolehan.

Barang berwujud yang memenuhi kualifikasi untuk diakui sebagai suatu aset dan dikelompokkan sebagai aset tetap, pada awalnya harus diukur berdasarkan biaya perolehan. Bila aset 
tetap diperoleh dengan tanpa biaya, biaya aset tersebut adalah sebesar nilai wajar pada saat aset tersebut diperoleh.

Pengeluaran setelah perolehan awal suatu aset tetap yang memperpanjang masa manfaat atau yang kemungkinan besar memberi manfaat ekonomi di masa yang akan datang dalam bentuk kapasitas, mutu produksi, atau peningkatan standar kinerja, harus ditambahkan pada nilai tercatat aset yang bersangkutan. Kapitalisasi biaya yang dimaksud harus ditetapkan dalam kebijakan akuntansi suatu entitas dan/atau suatu batasan jumlah biaya (capitalization thresholds) tertentu untuk dapat digunakan dalam penentuan apakah suatu pengeluaran harus dikapitalisasi atau tidak.

Penyusutan adalah alokasi sistematis jumlah yang dapat disusutkan dari suatu aset selama umur manfaatnya, Sugiri (2009:158). Pembebanan penyusutan merupakan pengakuan terjadinya penurunan nilai atas potensi manfaat (jasa) suatu aktiva. Pengalokasian beban penyusutan mencakup beberapa periode pendapatan sehingga banyak faktor yang harus dipertimbangkan oleh manajemen untuk menghitung besarnya beban penyusutan periodik secara tepat.

Didalam Peraturan Menteri Dalam Negeri No. 17 tahun 2007 tentang Pedoman Teknis Pengelolaan Barang Milik Daerah, penghapusan adalah tindakan menghapus barang milik Daerah dari daftar barang dengan menerbitkan surat keputusan dari pejabat yang berwenang untuk membebaskan pengguna dan/atau kuasa pengguna dan/atau pengelola dari tanggung jawab administrasi dan fisik atas barang yang berada dalam penguasaannya

Dalam Catatan atas Laporan Keuangan harus diungkapkan untuk masing-masing jenis aset tetap sebagai berikut: (1) .Dasar penilaian yang digunakan untuk menentukan nilai tercatat;(2).Rekonsiliasi jumlah tercatat pada awal dan akhir periode yang menunjukkan: (a) penambahan, (b) pelepasan, (c) akumulasi penyusutan dan perubahan nilai jika ada, dan (d) mutasi aset tetap lainnya;(3) Informasi penyusutan meliputi: (a) nilai penyusutan, (b) metode penyusutan yang digunakan, (c) masa manfaat atau tarif penyusutan yang digunakan, serta (d) nilai tercatat bruto dan akumulasi penyusutan pada awal dan akhir periode.

\section{Penelitian Terdahulu}

Persamaan penelitian ini dengan penelitian yang dilakukan oleh Auliana (2014) dan Tri Septiana (2011) yaitu sama-sama bertujuan untuk menganalisis perlakuan akuntansi aset tetap dan menggunakan metode penelitian yang sama yakni analisis deskriptif kualitaif. Sedangkan perbedaannya terletak pada objek penelitian yang di teliti dan standar akuntansi yang digunakan, Tri Septiana menggunakan PP Nomor 24 Tahun 2005 sedangkan peneliti menggunakan PP 71 Tahun 2010.

\section{Metode Penelitian}

\section{Jenis Penelitian}

Widi (2010 : 47) mendefinisikan bahwa penelitian deskriptif merupakan penelitian yang mencoba untuk memberikan gambaran secara sistematis tentang situasi, permasalahan, fenomena, layanan, atau program.

\section{Prosedur Penelitian}

a. Identifikasi Masalah, peneliti mengidentifikasi masalah yang akan diambil pada objek yang dipilih kemudian membuat latar belakang;

b. Rumusan Masalah, berdasarkan latar belakang yang ada kemudian peneliti merumuskan masalah yang akan dibahas;

c. Melakukan kunjungan langsung pada objek penelitian;

d. Pengumpulan data, peneliti nengumpulkan data-data yang diperlukan yang berhubungan dengan penelitian untuk menjadi dasar acuan bagi peneliti dalam melakukan penelitian; 
e. Analisis data, Peneliti mengolah data-data yang sesuai dengan dasar teori yang akan digunakan dalam penelitian;

f. Hasil penelitian, peneliti membuat kesimpulan berdasarkan data-data yang telah dianalisis yang telah disesuaikan dengan teori yang dipelajari.

\section{Metode Pengumpulan Data}

Metode yang digunakan dalam penelitian ini adalah studi lapangan. Metode ini digunakan untuk mengetahui seberapa jauh kesesuaian antara teori yang digunakan dengan keadaan yang sebenarnya dari objek yang diteliti. Dalam studi lapangan ini peneliti menggunakan tiga teknik pengumpulan data, yaitu :

\section{Metode Analisis}

Sugiyono (2011:21) menyatakan bahwa metode yang digunakan untuk menggambarkan dan menganalisis suatu hasil penelitian tetapi tidak digunakan untuk membuat kesimpulan yang lebih luas. Metode analisis yang digunakan oleh peneliti dalam penelitian ini adalah metode analisis deskriptif.

\section{HASIL PENELITIAN DAN PEMBAHASAN}

\subsection{Hasil Penelitian}

Kebijakan akuntansi yang berlaku di Badan Kepegawaian dan Diklat (BKD) Kota Manado merujuk pada Peraturan Walikota Manado Nomor 44 tahun 2014 dengan basis akuntansi yang digunakan yakni Cash Toward Accrual (CTA).. Periode akuntansi BKD untuk penyajian laporan keuangan adalah satu tahun menurut tahun takwim, yaitu 1 Januari s/d 31 Desember.

Badan Kepegawaian dan Diklat (BKD) Kota Manado merupakan Salah satu Satuan Kerja Perangkat Daerah (SKPD) yang ada di Kota Manado yang bertugas untuk membantu Walikota sebagai Pejabat pembina kepegawaian daerah kota Manado dalam melaksanakan manajemen kepegawaian daerah berdasarkan Peraturan Walikota Manado Nomor 38 Tahun 2008.

Pada SKPD ini aset tetap memiliki pengertian yang sama dengan pengertian aset tetap dalam Pernyataan Standar Akuntansi Pemerintahan, yaitu Aset berwujud yang mempunyai masa manfaat lebih dari 12 (dua belas) bulan untuk digunakan, atau dimaksudkan untuk digunakan, dalam kegiatan pemerintah atau dimanfaatkan oleh masyarakat umum. Untuk aset tetap dalam bentuk peralatan dan mesin dapat diakui sebagai aset tetap apabila biaya perolehan aset tetap tersebut lebih dari Rp. 300.000 sedangkan untuk aset tetap gedung dan bangunan akan diakui sebagai aset tetap apabila biaya perolehannya lebih dari Rp. 10.000.000.

Cara perolehan aset tetap pada Badan Kepegawaian dan Diklat (BKD) Kota Manado adalah perolehan barang langsung (LS). Aset tetap Badan Kepegawaian dan Diklat (BKD) Kota Manado terdiri dari:

1. Peralatan dan Mesin;

Jumlah peralatan dan mesin yang dimiliki oleh BKD Kota Manado adalah 181 buah, yang terdiri atas 5 alat angkutan dengan total nilai Rp. 413,075,000 dan 176 alat kantor dan rumah tangga di antaranya meja biro, lemari arsip, komputer, pendingin udara, mesin printer dengan total nilai alat kantor dan rumah tangga adalah sebesar Rp. 644,047,150.

2. Aset lain-lain;

Jumlah aset lain-lain yang dimiliki oleh BKD Kota Manado adalah 3 alat angkutan (Sepeda motor) dengan kondisi rusak berat yang bernilai Rp. 15,500,000.

3. Aset Tak Berwujud;

BKD Kota Manado memiliki 1 aset tak berwujud yakni aplikasi komputer Sistem Informasi Manajemen Kepegawaian (SIMPEG) yang bernilai Rp. 49,500,000. 
Daftar Jenis Aset tetap BKD Kota Manado

\begin{tabular}{|l|l|l|l|}
\hline No & Nama Bidang Barang & Jumlah Barang & $\begin{array}{l}\text { Jumlah Harga } \\
\text { Barang } \\
\text { ribuan) }\end{array}$ \\
\hline 1 & Peralatan dan Mesin & 181 & $1,057,122,150$ \\
\hline 2 & Aset Lain-lain & 3 & $15,500,000$ \\
\hline 3 & Aset Tak Berwujud & 1 & $49,500,000$ \\
\hline & Total Aset Tetap & & $1,122,122,150$ \\
\hline
\end{tabular}

(Sumber Data : Neraca BKD Kota Manado,2015)

\section{a. Pengakuan Aset Tetap}

Pada BKD Kota Manado suatu aset diakui sebagai aset tetap apabila aset tersebut mempunyai masa manfaat lebih dari 12 (dua belas) bulan yang ditentukan dengan menilai manfaat ekonomik yang dapat diberikan oleh pos tersebut dimasa yang akan datang, selain itu suatu aset tetap akan diakui sebagai aset tetap apabila terdapat bukti bahwa telah terjadi pembayaran atas aset tersebut.

Dalam hal memperoleh aset tetap BKD Kota Manado membuat perencanaan pengadaan barang yang kemudian melakukan perjanjian dengan pihak ketiga yang telah di tetapkan, pihak ketiga kemudian akan mengirimkan pengadaan aset tetap kepada BKD Kota Manado, selanjutnya BKD akan mengajukan surat perintah pembayaran dengan menyertakan dokumen yang di perlukan. Aset Tetap akan diakui pada saat terjadinya Berita Acara Serah Terima (BAST). Apabila beberapa aset tetap dibeli secara bersamaan dan tiap-tiap aset tidak disebutkan harganya, maka total harga yang dibebankan harus dialokasikan ke masing-masing aset yang bersangkutan.

Contohnya jika BKD melakukan pengadaan 5 (lima) unit komputer dengan masing-masing harga beli sebesar Rp. 5.000.000 maka jurnal yang akan dibuat adalah:

SKPD

Belanja Modal Peralatan dan Mesin- Komputer Rp. 25.000.000

RK-PPKD Rp. 25.000 .000

(untuk mencatat realisasi belanja modal perolehan peralatan dan mesin)

Jurnal Korolari untuk mengakui Peralatan dan Mesin

Peralatan dan Mesin- Komputer Rp. 25.000.000

Di investasikan dlm aset tetap- komputer $\quad$ Rp. 25.000.000

( untuk mencatat perolehan peralatan dan mesin)

Jurnal yang di buat oleh BUD

RK-SKPD

Rp. 25.000 .000

Kas Umum Daerah

Rp. 25.000 .000

( untuk mencatat realisasi pengeluaran kas untuk belanja modal peralatan dan mesin)

\section{b. Pengukuran Aset Tetap}

Menurut Standar Akuntansi Pemerintahan Pernyataan No.07 Tahun 2010, aset tetap dinilai dengan biaya perolehan. Apabila penilaian aset tetap dengan menggunakan biaya perolehan tidak memungkinkan maka nilai aset tetap didasarkan pada nilai wajar pada saat perolehan. Karena penilaian aset tetap dengan menggunakan biaya perolehan sangat memungkinkan pada BKD Kota Manado, maka pengukuran keseluruhan aset tetap yang dimiliki oleh BKD Kota Manado dinilai dengan biaya perolehan. 


\section{Penilaian Awal Aset Tetap}

Pada BKD Kota Manado, aset tetap dinilai dengan biaya perolehan. Biaya perolehan atas aset tetap yang dimiliki oleh BKD Kota Manado antara lain meliputi harga pembelian, biaya pengangkutan dan biaya instalasi untuk memperoleh dan mempersiapkan sampai aset tetap tersebut siap dipergunakan.

Contohnya, BKD Kota Manado melakukan pengadaan AC sebanyak 5 unit. Untuk 1 unit AC harganya Rp. 4.000.000 kemudian Biaya pemasangan untuk AC tersebut Rp. 350.000 untuk setiap unit. Maka jurnal yang dibuat adalah:

SKPD

Belanja Modal Peralatan dan Mesin- ACRp. 25.000.000

RK-PPKD

Rp. 25.000 .000

(untuk mencatat realisasi belanja modal perolehan peralatan dan mesin)

Jurnal Korolari untuk mengakui Peralatan dan Mesin

Peralatan dan Mesin- AC Rp. 25.000.000

Di investasikan dlm aset tetap- AC Rp. 25.000.000

( untuk mencatat perolehan peralatan dan mesin)

Jurnal yang di buat oleh BUD

RK-SKPD

Kas Umum Daerah

Rp. 25.000 .000

Rp. 25.000 .000

( untuk mencatat realisasi pengeluaran kas untuk belanja modal peralatan dan mesin)

\section{c. Pengeluaran Setelah Perolehan (Subsequent Expenditure)}

Dalam hal pengeluaran setelah perolehan, Badan Kepegawaian dan Diklat (BKD) Kota Manado tidak menetapkan batasan jumlah biaya yang dikapitalisasi terhadap aset tetap. Oleh sebab itu, hingga saat ini belum ada pengeluaran setelah perolehan yang dikapitalisasi pada aset tetap yang bersangkutan. Pengeluaran-pengeluaran yang terjadi adalah pengeluaran yang tidak memperpanjang masa manfaat aset yang diperlakukan sebagai biaya. Contoh jurnal untuk perlakuan ini adalah :

SKPD

Belanja Pemeliharaan

Piutang dari KUD

BUD

$$
\text { Rp. } 2.500 .000
$$

Rp. 2.500 .000

$$
\text { Rp. } 2.500 .000
$$

Rp. 2.500 .000

\section{d. Penyusutan}

Badan Kepegawaian dan Diklat (BKD) Kota Manado belum pernah melakukan penyusutan aset tetap. Belum dilakukannya penyusutan atas aset tetap di karenakan belum adanya prosedur dan petunjuk teknis penyusutan aset tetap yang diatur dalam kebijakan akuntansi aset tetap pemerintah daerah. Oleh sebab itu, semua aset tetap yang dimiliki oleh BKD Kota Manado disajikan dalam neraca sesuai dengan biaya perolehan saat pembelian. Di karenakan belum adanya petunjuk teknis mengenai penyusutan maka aset tetap yang sudah lebih masa manfaatnya namun masih dalam kondisi layak pakai maka aset tetap tersebut tetap di sajikan dalam neraca dengan biaya perolehan saat awal pembelian. 


\section{e. Penghentian dan Pelepasan (Retirement and Disposal)}

Pada BKD Kota Manado apabila terdapat aset tetap yang dihentikan dari penggunaan aktif pemerintah maka aset tetap tersebut dipindahkan ke pos aset lainnya sesuai dengan nilai tercatatnya. Kemudian, atas aset tetap yang dihentikan dari penggunaan aktif pemerintah tersebut BKD Kota Manado membuat daftar usulan barang yang akan dihapus. Apabila usulan penghapusan tersebut diterima maka aset tetap tersebut dieliminasi dari neraca yang kemudian diungkapkan dalam Catatan atas Laporan Keuangan. Namun hingga saat peneliti melakukan penelitian pada BKD Kota Manado, daftar usulan barang yang akan dihapus belum di proses. Jadi, aset-aset tersebut disajikan sebagai aset lain-lain.

\section{f. Pengungkapan}

Badan Kepegawaian dan Diklat (BKD) Kota Manado mengungkapkan kebijakan akuntansi yang berlaku serta informasi mengenai pos-pos aset tetap dalam Catatan atas Laporan Keuangan (CaLK).

\section{Pembahasan}

Berikut ini akan disajikan tabel analisis perbandingan perlakuan akuntansi aset tetap pada BKD Kota Manado dengan Peraturan Pemerintah No. 71 tahun 2010 pernyataan No. 07 tentang Aset Tetap.

\section{Tabel 4.1}

Perbandingan pengakuan Aset Tetap oleh BKD Kota Manado dengan PSAP No. 07

PSAP Nomor 07

a. Masa manfaat lebih dari 12 (dua belas) bulan.

b. Biaya perolehan dapat diukur secara andal.

c. Tidak dimaksudkan dalam operasi normal entitas.

d. Diperoleh atau dibangun dengan maksud untuk digunakan.

e. Pengakuan aset tetap akan sangat andal apabila aset tetap telah diterima atau diserahkan hak

kepemilikannya pada saat penguasaannya berpindah.

\section{BKD Kota Manado Keterangan}

a. Pengakuan aset tetap Sesuai

terjadi jika aset tetap yang dimiliki memberikan manfaat ekonomik masa depan.

b. Biaya perolehan dapat Sesuai diukur secara andal.

c. Tidak dimaksudkan untuk Sesuai dijual dalam operasi normal entitas

d. Diperoleh atau dibangun Sesuai dengan maksud untuk digunakan.

e. Pengakuan aset tetap Sesuai dicatat berdasarkan tanggal perolehan aset tersebut.

(Sumber : Olahan, 2015)

Dari tabel perbandingan pengakuan aset tetap di atas terlihat bahwa perlakuan akuntansi aset tetap yang ada di BKD Kota Manado telah sesuai dengan peraturan pemerintah yang berlaku. 


\section{Tabel 4.2}

Perbandingan pengukuran Aset Tetap oleh BKD Kota Manado dengan Pengukuran Aset Tetap berdasarkan PSAP No.07

PSAP No. 07

a. Aset tetap dinilai dengan biaya perolehan. Apabila penilaian aset tetap dengan menggunakan biaya perolehan tidak memungkinkan maka nilai aset tetap didasarkan pada nilai wajar pada saat perolehan.

b. Biaya Perolehan suatu aset tetap terdiri dari harga harga belinya atau konstruksinya,termasuk bea impor dan setiap biaya yang dapat diatribusikan secara langsung.

\section{BKD Kota Manado Keterangan}

a. Aset tetap dinilai dengan Sesuai biaya perolehan.

b. Biaya perolehan suatu Sesuai aset terdiri dari harga beli, biaya angkut, dan biaya pemasangan.

(Sumber : Olahan, 2015)

Berdasarkan tabel perbandingan pengukuran aset tetap di atas, perlakuan akuntansi aset tetap pada BKD Kota Manado telah sesuai dengan peraturan pemerintah yang berlaku.

Tabel 4.3

Perbandingan Pengeluaran Setelah Perolehan oleh BKD Kota Manado dengan berdasarkan PSAP No. 07

\begin{tabular}{|c|c|c|}
\hline PSAP No. 07 & BKD Kota Manado & Keterangan \\
\hline $\begin{array}{l}\text { a. Pengeluaran setelah } \\
\text { perolehan awal suatu aset } \\
\text { tetap yang memperpanjang } \\
\text { masa manfaat atau yang } \\
\text { kemungkinan besar memberi } \\
\text { manfaat ekonomik di masa } \\
\text { yang akan datang dalam } \\
\text { bentuk kapasitas, mutu } \\
\text { produksi atau peningkatan } \\
\text { standar kinerja, harus } \\
\text { ditambahkan pada nilai } \\
\text { tercatat aset yang } \\
\text { bersangkutan. }\end{array}$ & $\begin{array}{l}\text { a. Pengeluaran untuk perbaikan } \\
\text { atau perawatan aset tetap } \\
\text { yang memperpanjang masa } \\
\text { manfaat atau hanya akan } \\
\text { memberi manfaat dalam } \\
\text { periode berjalan, tidak akan } \\
\text { dikapitalisasi sebagai aset } \\
\text { tetap di neraca, melainkan } \\
\text { akan langsung dibebankan } \\
\text { sebagai beban dalam laporan } \\
\text { laba rugi periode berjalan } \\
\text { dimana biaya terjadi } \\
\text { (dikeluarkan). }\end{array}$ & Sesuai \\
\hline
\end{tabular}

(Sumber : Olahan, 2015)

Pada tabel perbandingan pengeluaran setelah perolehan di atas, perlakuan yang di terapkan pada BKD Kota Manado sudah sesuai dengan peraturan pemerintah yang berlaku. 


\section{Tabel 4.4}

Perbandingan penyusutan oleh BKD Kota Manado dengan berdasarkan PSAP No 07

PSAP No. $07 \quad$ BKD Kota Manado $\quad$ Keterangan

a. Nilai penyusutan untuk a. Belum dilakukan Belum Sesuai masing-masing periode diakui penyusutan dikarenakan sebagai pengurang nilai belum dikeluarkannya surat tercatat aset tetap dan keputusan tentang melakukan diinvestasikan dalam aset penyesuaian nilai aset tetap. tetap.

(Sumber : Olahan, 2015)

Berdasarkan tabel perbandingan penyusutan di atas, terlihat bahwa perlakuan akuntansi yang diterapkan oleh BKD Kota Manado belum sesuai dengan peraturan pemerintah yang berlaku tentang penyusutan suatu aset tetap.

Tabel 4.5

Perbandingan Penghentian dan Pelepasan oleh BKD Kota Manado dan yang berdasarkan PSAP No. 07

PSAP No. 07

a. Aset tetap dieliminasi dari neraca ketika dilepaskan atau bila aset secara permanen dihentikan penggunaannya dan tidak ada manfaat ekonomik masa yang akang datang.

b. Aset tetap yang dihentikan dari penggunaan aktif pemerintah tidak memenuhi definisi aset tetap dan harus dipindahkan kepos aset lainnya.

\section{BKD Kota Manado}

a. Suatu aset dilepaskan atau dihentikan penggunaannya apabila aset tersebut tidak ada manfaat ekonomik di masa yang akan datang.

b. Suatu aset dipindahkan ke pos aset lainnya apabila aset tersebut telah dihentikan dari penggunaan aktif pemerintah.

Keterangan

Sesuai

Sesuai

(Sumber : Olahan, 2015)

Pada tabel perbandingan penghentian dan pelepasan aset tetap di atas, terlihat bahwa perlakuan akuntansi aset tetap tentang penghentian dan pelepasan yang di terapkan pada BKD Kota Manado sudah sesuai dengan peraturan pemerintah yang berlaku.

\section{Tabel 4.6}

Perbandingan Pengungkapan Aset Tetap oleh BKD Kota Manado dengan yang berdasarkan PSAP No. 07

\begin{tabular}{lrlrl}
\hline PSAP No. 07 & \multicolumn{2}{l}{ BKD Kota Manado } & Keterangan \\
a. Laporan keuangan harus & a. Penyajian aset tetap & Sesuai \\
mengungkapkan dasar penilaian & dinyatakan sebesar biaya & \\
yang digunakan untuk & perolehan aset yang & \\
menentukan nilai tercatat. & bersangkutan. & &
\end{tabular}




\begin{tabular}{|c|c|c|}
\hline $\begin{array}{l}\text { b. setiap jenis aset seperti tanah, } \\
\text { gedung dan bangunan, peralatan } \\
\text { dan mesin dan lain sebagainya } \\
\text { harus dinyatakan dalam neraca } \\
\text { secara terpisah atau terperinci } \\
\text { dalam catatan atas laporan } \\
\text { keuangan. }\end{array}$ & $\begin{array}{l}\text { b. setiap jenis aset tetap } \\
\text { dinyatakan dalam neraca } \\
\text { secara terpisah atau diperinci } \\
\text { pada catatan atas laporan } \\
\text { keuangan. }\end{array}$ & Sesuai \\
\hline $\begin{array}{l}\text { c. Rekonsiliasi jumlah tercatat } \\
\text { pada awal dan akhir periode } \\
\text { yang } \\
\text { penambahan, pelepasan, } \\
\text { akumulasi penyusutan dan } \\
\text { perubahan nilai jika ada mutasi } \\
\text { aset tetap lainnya. }\end{array}$ & $\begin{array}{l}\text { c. laporan keuangan } \\
\text { mengungkapkan rekonsiliasi } \\
\text { jumlah tercatat yang } \\
\text { menunjukkan pelepasan dan } \\
\text { mutasi aset tetap lainnya. }\end{array}$ & Sesuai \\
\hline
\end{tabular}

Berdasarkan tabel perbandingan pengungkapan aset tetap di atas, terlihat bahwa BKD Kota Manado telah menerapkan perlakuan yang sama dengan peraturan pemerintah yang berlaku mengenai pengungkapan suatu aset tetap.

\section{KESIMPULAN}

Berdasarkan hasil penelitian dan pembahasan yang telah dilakukan dalam menganalisis perlakuan akuntansi aset tetap pada Badan Kepegawaian dan Diklat Kota Manado maka dapat ditarik kesimpulan sebagai berikut :

1. Pengakuan aset tetap pada Badan Kepegawaian dan Diklat (BKD) Kota Manado telah sesuai dengan SAP No. 07.

2. Pengukuran/Penilaian aset tetap pada Badan Kepegawaian dan Diklat (BKD) Kota Manado telah sesuai dengan SAP No. 07.

3. Dalam hal Pengeluaran Setelah Perolehan Badan Kepegawaian dan Diklat (BKD) Kota Manado sudah sesuai dengan SAP No. 07.

4. Badan Kepegawaian dan Diklat (BKD) Kota Manado belum pernah melakukan penyusutan atas aset tetap dikarenakan belum adanya prosedur petunjuk teknis penyusutan aset tetap.

5. Penghentian dan Pelepasan aset tetap Badan Kepegawaian dan Diklat (BKD) Kota Manado sudah sesuai dengan SAP No. 07.

6. Dalam hal Pengungkapan Aset Tetap dalam Laporan Keuangan, BKD Kota Manado telah menyajikan informasi yang berkaitan dengan aset tetap secara terperinci.

Adapun saran yang bisa diajukan adalah :

1. Secara umum perlakuan akuntansi aset tetap pada Badan Kepegawaian dan Diklat Kota Manado sudah baik namun akan lebih baik lagi apabila Badan Kepegawaian dan Diklat Kota Manado segera melakukan penyusutan atas aset tetap yang dimiliki, mengingat pentingnya penyusutan terhadap suatu aset.

2. Bagi pemerintah kota Manado, diharapkan agar segera mengeluarkan peraturan tentang prosedur dan teknis penyusutan atas aset tetap agar setiap SKPD yang ada di Kota Manado dapat melakukan penyusutan terhadap aset tetap yang dimiliki. Aset tetap perlu disusutkan karena aset tetap dengan berlalunya waktu akan mengalami penurunan kapasitas dalam memberikan jasa selain itu penyusutan aset tetap perlu dilakukan agar suatu entitas mengalokasikan cost dari aset tetap ke masa manfaat dari aset tetap yang bersangkutan. 


\section{DAFTAR PUSTAKA}

Auliana. 2014. Analisis Akuntansi Aset Tetap Pada Badan Penanggulangan Bencana Daerah Kota Tanjung Pinang Berdasar Pernyataan Standar Akuntansi Pemerintahan No. 07. Skripsi (tidak dipublikasikan). Fakultas Ekonomi Universitas Maritim Raja Ali Haji. Tanjungpinang.

Ghozali, Imam, Ratnomo, Dwi. 2008. Akuntansi Keuangan Pemerintah Pusat (APBN) dan Daerah (APBD) sesuai peraturan Perundang-Undangan Terbaru. Badan Penerbit Universitas Diponegoro. Semarang.

Hery. 2011. Akuntansi Aktiva, Hutang dan Modal. Edisi Kesebelas. Gava Media. Jakarta.

Ismail. 2010. Akuntansi Bank. PT Kencana, Surabaya.

Komite Standar Akuntansi Pemerintahan, Peraturan Pemerintah Republik Indonesia Tahun 2010 Tentang Standar Akuntansi Pemerintahan.

M. Yusuf. 2010. Delapan Langkah Pengelolaan Aset Daerah Menuju Pengelolaan Keuangan Daerah Terbaik. Salemba Empat. Jakarta

Nordiawan,Deddi,Putra,Sondi I. Rahmawati,Maulida.2012.Akuntansi Sektor Publik. Salemba Empat. Jakarta.

Peraturan Walikota Manado Nomor 44 tahun 2014.

Restu Wedi Kartiko, 2010. Asas Metodologi Penelitian. Graha Ilmu. Jakarta

Sodikin, Riyono. 2014. Akuntansi Pengantar 1. UPP STIM YKPN

Sugiyono. 2011. Metode Penelitian Kuantitatif dan Kualitatif. Alfabeta. Bandung

Sugiri, Slamet. 2009. Akuntansi Suatu Pengantar 2. Edisi Kelima. UPP STIM YKPN,Yogyakarta.

Suhayati, Ely. 2009. Akuntansi Keuangan. Edisi Pertama.Graha Ilmu, Yogyakarta. Suwardjono. 2013. Akuntansi Pengantar. Edisi Keenam. BPFE, Yogyakarta.

Septiana Tri. 2011. Analisis Akuntansi Aset Tetap Pada Dinas Tenaga Kerja dan

Transmigrasi Kabupaten Bungon Berdasarkan Standar Akuntansi Pemerintahan(PP 24 Tahun 2005). Skripsi (tidak dipublikasikan). Fakultas Ekonomi Universitas Andalas. Padang. 